\title{
Entrepreneurship in Nursing: an integrative literature review
}

\author{
Empreendedorismo na Enfermagem: revisão integrativa da literatura \\ Emprendedorismo en la enfermería: revisión integrativa de la literatura
}

Fernanda Hannah da Silva Copelli'
ORCID: 0000-0002-5914-2922

Alacoque Lorenzini Erdmann' ORCID: 0000-0003-4845-8515

José Luís Guedes dos Santos' ORCID: 0000-0003-3186-8286

'Universidade Federal de Santa Catarina. Florianópolis, Santa Catarina, Brazil.

How to cite this article: Copelli FHS, Erdmann AL, Santos JLG. Entrepreneurship in Nursing: an integrative literature review. Rev Bras Enferm [Internet]. 2019;72(Suppl 1):289-98. [Thematic Issue: Work and Management in Nursing]. DOI: http://dx.doi.org/ 10.1590/0034-7167-2017-0523

Corresponding Author:

Fernanda Hannah da Silva Copelli E-mail: fernandacopelli@hotmail.com

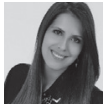

Submission: 07-24-2017

Approval: 12-09-2017

\section{ABSTRACT}

Objective: To demonstrate in the national and international literature the concept and typologies of entrepreneurship in Nursing. Method: Integrative review in six databases, with the descriptors entrepreneurship, entrepreneurs, entrepreneurial, entrepreneurialism, intrapreneurial, iniciativa empresarial, contrato de risco, nursing, nurse, nurses, enfermagem and enfermeira, making a final sample of 31 articles. Results: The concept of entrepreneurship in Nursing is related to personal and professional characteristics, such as autonomy, independence, flexibility, innovation, proactivity, self-confidence and responsibility. The typologies found were: social and business entrepreneurship, and intrapreneurship. Social entrepreneurship is a mechanism of social mobilization and transformation, entrepreneurship is one in which nurses are autonomous professionally and intrapreneurship relates to corporate entrepreneurs. Conclusion: Entrepreneurship can increase the visibility of the profession and foster the creation of new spaces for nurses.

Descriptors: Risk Contract; Nursing; Nursing Administration Research; Administration; Nurse Administrators.

\section{RESUMO}

Objetivo: Evidenciar na literatura nacional e internacional o conceito e as tipologias de empreendedorismo na Enfermagem. Método: Revisão integrativa em seis bases de dados, com os descritores entrepreneurship, entrepreneurs, entrepreneurial, entrepreneurialism, intrapreneurial, iniciativa empresarial, contrato de risco, nursing, nurse, nurses, enfermagem e enfermeira, perfazendo uma amostra final de 31 artigos. Resultados: $O$ conceito de empreendedorismo na Enfermagem está relacionando a características pessoais e profissionais, como autonomia, independência, flexibilidade, inovação, pró-atividade, autoconfiança e responsabilidade. As tipologias encontradas foram: empreendedorismo social, empresarial e intraempreendedorismo. Oempreendedorismo social é um mecanismo de mobilização e transformação social, empreendedorismo empresarial é aquele no qual enfermeiros são autônomos profissionalmente e o intraempreendedorismo relaciona-se a empreendedores empregados coorporativos. Conclusão: $\mathrm{O}$ empreendedorismo pode ampliar a visibilidade da profissão e fomentar a criação de novos espaços de atuação para o enfermeiro.

Descritores: Contrato de Risco; Enfermagem; Pesquisa em Administração de Enfermagem; Administração; Enfermeiras Administradoras.

\section{RESUMEN}

Objetivo: Evidenciar en la literatura nacional e internacional el concepto y las tipologías de emprendedorismo en la enfermería. Método: La revisión integrativa en seis bases de datos, con los descriptores entrepreneurship, entrepreneurs, entrepreneurial, entrepreneurialism, intrapreneurial, iniciativa empresarial, contrato de risco, nursing, nurse, nurses, enfermagem y enfermeira, con una muestra final de 31 artículos. Resultados: El concepto de emprendedorismo en la enfermería está relacionando a características personales y profesionales, como autonomía, independencia, flexibilidad, innovación, proactividad, autoconfianza y responsabilidad. Las tipologías encontradas fueron: emprendimiento social, empresarial e intra-empresarial. El emprendedorismo social es un mecanismo de movilización y transformación social, emprendedorismo empresarial es aquel en el cual enfermeros son autónomos profesionalmente y el intraemprendedorismo se relaciona con emprendedores empleados corporativos. Conclusión: El emprendedorismo puede ampliar la visibilidad de la profesión y fomentar la creación de nuevos espacios de actuación para el enfermero.

Descriptores: Contrato de Riesgo; Enfermería; Investigación en Administración de Enfermería; Administración; Enfermeras Administradoras. 


\section{INTRODUCTION}

The term entrepreneurship emerged around the fifteenth century through the French words entrepreneur or entreprende, which means organizing, managing and taking risks in a business or enterprise. Entrepreneurship can be defined as an action to achieve success through the coordination and performance of projects, services and businesses ${ }^{(2)}$. However, there is no consensus on the concept of entrepreneurship, since the term has assumed, over the years, specificities according to the contributions and interpretations of several authors, assigning it a polysemic and multidisciplinary character.

The concept of entrepreneurship was initially discussed in the economic sphere. However, it has spread to other areas of knowledge, such as social, political and institutional ${ }^{(2)}$. Entrepreneurship for economists, for example, is associated with economic development and the entrepreneur, consequently, the promotion and propulsion of innovation for this development. For behaviorists, entrepreneurship is related to entrepreneurial behavior and attitudes ${ }^{(3)}$.

In Nursing, entrepreneurship has been evident since the nineteenth century, through pioneering work by Florence Nightingale in the care for soldiers during the Crimean War and the founding of the School of Nursing at Saint Thomas Hospital, initiating the scientific foundations of profession. Other examples of entrepreneurial figures in Nursing are: Anna Nery, who worked in the care for the wounded in the Paraguayan War, and Wanda de Aguiar Horta, the first Brazilian theorist of the profession ${ }^{(4)}$.

In the contemporary context, entrepreneurship in Nursing is important for the expansion of visibility and consolidation of the profession as science, technology and innovation in the most diverse settings and fields of action ${ }^{(5)}$. Only then, society can know the advances of the profession, through its social mission and health gains ${ }^{(6)}$. The approach to the concept of entrepreneurship, therefore, guides the promotion of social visibility of Nursing, as well as the reach of new levels of professional development to the nurses.

Despite the importance of entrepreneurship in Nursing, this theme is still little discussed in the literature ${ }^{(7)}$. This indicates the need to broaden discussions about the concept of entrepreneurship in Nursing and to know which typologies, areas and/ or sectors of action are the entrepreneurial nurses.

\section{OBJECTIVE}

To demonstrate the concept and typologies of entrepreneurship in Nursing described in the national and international literature.

\section{METHOD}

\section{Type of study}

It is an integrative review of the literature ${ }^{(8)}$. This method makes it possible to analyze the existing literature, providing a comprehensive understanding of a particular object of study. It can be applied in several themes and/or study designs, contributing to the practice of Nursing based on scientific evidence ${ }^{(8)}$.

\section{Methodological procedures}

For the preparation of this study, the following steps were followed: formulation of the problem and research question together with the elaboration of the review protocol; approval of the protocol; data collect; analysis and interpretation of data; organization of data into categories; and presentation of results and conclusions ${ }^{(8)}$.

\section{Collection and organization of data}

Data collection was performed in April 2017, in the databases: Latin American and Caribbean Literature in Health Sciences (LILACS), Publisher Medline (PUBMED), SciVerse Scopus (SCOPUS), Cumulative Index to Nursing and Allied Health (CINAHL), Scientific Electronic Library Online (SciELO) and Nursing Databases (BDENF - Bases de Dados de Enfermagem), using the following descriptors and keywords: entrepreneurship, entrepreneurs, entrepreneurial, entrepreneurialism, intrapreneurial, entrepreneurship, risk contract, nursing , nurse, nurses, nursing and nursing.

Combinations were made between the descriptors and/or keywords that originated the search strategies described below (Chart 1):

Chart 1 - Search strategies

\begin{tabular}{|c|c|}
\hline $\begin{array}{l}\text { LILACS } \\
\text { and } \\
\text { BDENF }\end{array}$ & $\begin{array}{l}\text { (tw: ((entrepreneurship OR entrepreneurs OR entrepreneurial } \\
\text { OR entrepreneurialism OR intrapreneurial OR empreende* } \\
\text { OR intraempreende* OR "iniciativa empresarial" OR"contrato } \\
\text { de risco"))) AND (tw: ((nursing OR nurse* OR enfermagem } \\
\text { OR enfermeir* OR enfermeria OR enfermer*))) AND (instance: } \\
\text { "regional") AND ( } \mathrm{db} \text { ( ("LILACS" OR "BDENF")) }\end{array}$ \\
\hline PUBMED & $\begin{array}{l}\text { ("entrepreneurship" [MeSH Terms] OR "entrepreneurship" [All } \\
\text { Fields] OR entrepreneurs [All Fields] OR entrepreneurial [All } \\
\text { Fields] OR entrepreneurialism [All Fields] OR intrapreneurial } \\
\text { [All Fields]) AND ("nursing" [Subheading] OR "nursing" [All } \\
\text { Fields] OR "nursing" [MeSH Terms] OR "nurses" [MeSH Terms] } \\
\text { OR "nurses" [All Fields] OR "nurse" [All Fields]) AND (English } \\
\text { [lang] OR Portuguese [lang] OR Spanish [lang]) }\end{array}$ \\
\hline SCOPUS & $\begin{array}{l}\text { (TITLE-ABS-KEY (entrepreneurship OR entrepreneurs OR } \\
\text { entrepreneurial OR entrepreneurialism OR intrapreneurial) } \\
\text { AND TITLE-ABS-KEY (nursing OR nurses OR nurse)) }\end{array}$ \\
\hline CINAHL & $\begin{array}{l}\text { (entrepreneurship OR entrepreneurs OR entrepreneurial OR } \\
\text { entrepreneurialism OR intrapreneurial)) AND ((nursing OR } \\
\text { nurses OR nurse)) }\end{array}$ \\
\hline SCIELO & $\begin{array}{l}\text { (entrepreneurship OR entrepreneurs OR entrepreneurial OR } \\
\text { entrepreneurialism OR intrapreneurial OR empreende\$ OR } \\
\text { intraempreende\$ OR“iniciativa empresarial") AND (nursing } \\
\text { OR nurse\$ OR enfermagem OR enfermeir\$ OR enfermeria OR } \\
\text { enfermer\$) }\end{array}$ \\
\hline
\end{tabular}

\section{Data analysis}

From the data collection, 1,194 studies were located, which were submitted to the first stage of evaluation through the application of inclusion and exclusion criteria previously defined in the research protocol. The inclusion criteria adopted were: original research articles published in a complete, free and free manner in journals available in the selected databases, in the Portuguese, English and Spanish languages, in accordance with the proposed objective and the descriptors and/or keywords listed in the previously validated protocol. Articles that were in more than one database were considered duplicates and automatically deleted. 


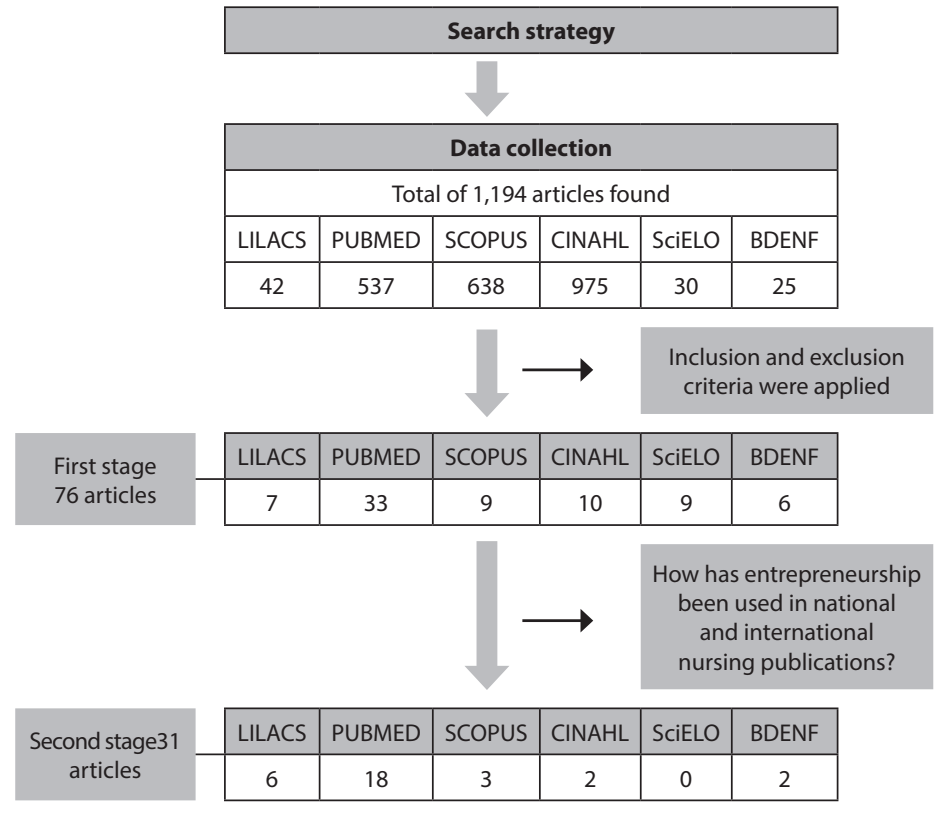

Figure 1 - Collection and analysis of data flowchart

Thus, a sample of 76 studies were obtained at the end of the first evaluation stage of the articles, of which $7(14.08 \%)$ were found in LILACS, 33 (43.66\%) in PUBMED, 9 (15.49\% \%) in
SCOPUS, 10 (14.08\%) in CINAHL, 9 (5.63\%) in SciELO and $6(7.04 \%)$ in BDENF.

In the second stage, the 76 studies were completely read to identify those that answered satisfactorily to the research question and/or were pertinent to the purpose of the study. From this process, a sample of 31 articles were included, being 6 (15.38\%) of LILACS, 18 (61.53\%) of PUBMED, 3 (30.76\%) of SCOPUS, 2 (2.81 \%) of CINAHL, none (0\%) of SCiELO and 2 (3.84\%) of BDENF. The flowchart with the detailing of the research stages is presented below in Figure 1.

The analysis and interpretation of the data were done in an organized way by visualizing the data in an Excel table, which included the following synthesis columns: study title, database, journal, year of publication, country of development study, context/place of study, methodological design, typology of entrepreneurship, results and reflections of the authors.

\section{RESULTS}

The results begin with a description of the characteristics of the 31 studies ${ }^{(0-39)}$ included in this review (Chart 2). In the sequence, the two categories are evidenced from the results of the selected studies: Concept of Entrepreneurship in Nursing; and Typologies of Entrepreneurship in Nursing.

Chart 2 - Characteristics of selected studies

\begin{tabular}{|c|c|c|c|c|}
\hline Title & Year/Journal & Background & Approach & Context \\
\hline Education of nurses under the social enterprising view ${ }^{(16)}$ & 2009 Revista Gaúcha de Enfermagem & Brazil & Qualitative & Education \\
\hline Business characteristics of the future nurse $\mathrm{e}^{(10)}$ & 2013 Cogitare Enfermagem & Brazil & Qualitative & Education \\
\hline $\begin{array}{l}\text { Enterprise teaching in Undergraduate Nursing Course at } \\
\text { University Paulista (UNIP) Goiânia - Goiás( }\end{array}$ & $\begin{array}{l}2008 \text { Revista do Instituto de Ciências } \\
\text { da Saúde }\end{array}$ & Brazil & Quantitative & Education \\
\hline $\begin{array}{l}\text { Nursing care as an enterprising social practice: } \\
\text { opportunities and possibilities }{ }^{(17)}\end{array}$ & 2010 ACTA Paulista de Enfermagem & Brazil & Qualitative & Care \\
\hline Autonomous and business practices in nursing ${ }^{(11)}$ & 2013 Cogitare Enfermagem & Brazil & Quantitative & Business \\
\hline $\begin{array}{l}\text { Advanced practice nurse entrepreneurs in } \\
\text { multidisciplinary surgical-assisting partnership }{ }^{(12)}\end{array}$ & $\begin{array}{l}2005 \text { AORN Jornal - Home Study } \\
\text { Program }\end{array}$ & USA & Qualitative & Education \\
\hline $\begin{array}{l}\text { Rising to the Challenge of Health Care Reform with } \\
\text { Entrepreneurial and Intrapreneurial Nursing Initiatives }\end{array}$ & $\begin{array}{l}2012 \text { The Online Journal of Issues in } \\
\text { Nursing }\end{array}$ & USA & Qualitative & Care \\
\hline $\begin{array}{l}\text { A nurse and a civil cervant changinginstitutions: } \\
\text { entrepreneurial processes in different public sector } \\
\text { organizations }^{(36)}\end{array}$ & $\begin{array}{l}2008 \text { Scandinavian Journal of } \\
\text { Management }\end{array}$ & Sweden & Qualitative & Business \\
\hline Entrepreneurship The Realities of Today $y^{(30)}$ & 1994 Journal of Nurse-Midiwifery & USA & Qualitative & Business \\
\hline $\begin{array}{l}\text { Self-employed nurses as change agents in healthcare: } \\
\text { strategies, consequences, andpossibilities }{ }^{(26)}\end{array}$ & $\begin{array}{l}2014 \text { Journal of Health Organization } \\
\text { and Management }\end{array}$ & Canada & Qualitative & Business \\
\hline Education for entrepreneurship in nursing ${ }^{(19)}$ & 2011 Nurse Education Today & $\begin{array}{l}\text { United } \\
\text { Kingdom }\end{array}$ & Qualitative & Education \\
\hline Are rural health professionals also social entrepreneurs? & 2009 Social Science \& Medicine & $\begin{array}{l}\text { Scotland and } \\
\text { Australia }\end{array}$ & Qualitative & Care \\
\hline $\begin{array}{l}\text { Barriers to nurse entrepreneurship: A study of the process } \\
\text { model of entrepreneurship }\end{array}$ & $\begin{array}{l}2007 \text { Journal of the American } \\
\text { Academy of Nurse Practitioners }\end{array}$ & USA & Qualitative & $\begin{array}{c}\text { Care, } \\
\text { Management } \\
\text { and Education }\end{array}$ \\
\hline $\begin{array}{l}\text { Clinical nurse specialists as entrepreneurs: constrained or } \\
\text { liberated }^{(29)}\end{array}$ & 2006 Journal of clinical nursing & $\begin{array}{l}\text { United } \\
\text { Kingdom }\end{array}$ & Qualitative & Care \\
\hline $\begin{array}{l}\text { Decreasing barriers for nurse practitioner social } \\
\text { entrepreneurship }^{(28)}\end{array}$ & $\begin{array}{l}2014 \text { Journal of the American } \\
\text { Association of Nurse Practitioners }\end{array}$ & USA & Qualitative & $\begin{array}{l}\text { Care and } \\
\text { Management }\end{array}$ \\
\hline
\end{tabular}


Chart 2 (concluded)

\begin{tabular}{|c|c|c|c|c|}
\hline Title & Year/Journal & Background & Approach & Context \\
\hline Do nursing students have entrepreuner profile? ${ }^{(22)}$ & $\begin{array}{l}2009 \text { Revista Brasileira de } \\
\text { Enfermagem }\end{array}$ & Brazil & Quantitative & Education \\
\hline $\begin{array}{l}\text { How nurses can use social enterprise to improve services } \\
\text { in health } \operatorname{care}^{(18)}\end{array}$ & 2009 Nursing Times & $\begin{array}{l}\text { United } \\
\text { Kingdom }\end{array}$ & Qualitative & Care \\
\hline $\begin{array}{l}\text { Moving from institutional dependence to } \\
\text { entrepreneurialism. Creating and funding a collaborative } \\
\text { research and practice development position }{ }^{(37)}\end{array}$ & 2005 Journal Clinical Nursing & Australia & Qualitative & Care \\
\hline $\begin{array}{l}\text { New skills required of nurse tutors in the UK: a study within } \\
\text { two project } 2000 \text { pilot schemes for pre-registration nursing } \\
\text { courses }^{(39)}\end{array}$ & 1998 Nurse Education Today & $\begin{array}{l}\text { United } \\
\text { Kingdom }\end{array}$ & Quantitative & $\begin{array}{l}\text { Education and } \\
\text { Management }\end{array}$ \\
\hline $\begin{array}{l}\text { Nurse entrepreneurs attitudes to management, their adoption } \\
\text { of the manager s role and managerial assertiveness }{ }^{(34)}\end{array}$ & $\begin{array}{l}2008 \text { Journal of Nursing } \\
\text { Management }\end{array}$ & Finland & Quantitative & Management \\
\hline $\begin{array}{l}\text { Nursing entrepreneurship: motivators, strategies and } \\
\text { possibilities for professional advancement and health } \\
\text { system change }^{(27)}\end{array}$ & 2013 Nursing Leadership & Canada & Qualitative & $\begin{array}{c}\text { Care and } \\
\text { Management }\end{array}$ \\
\hline $\begin{array}{l}\text { The role of the nurse in the Brazilian Unified Heath System: } \\
\text { from community health to the family health strategy }{ }^{(25)}\end{array}$ & 2012 Ciência e Saúde Coletiva & Brazil & Qualitative & Care \\
\hline Promoting citizenship through nursing care ${ }^{(20)}$ & $\begin{array}{l}2009 \text { Revista Brasileira de } \\
\text { Enfermagem }\end{array}$ & Brazil & Qualitative & Care \\
\hline Enterprising tendencies of nurses in a university hospital ${ }^{(14)}$ & 2013 Revista Gaúcha de Enfermagem & Brazil & Quantitative & Care \\
\hline $\begin{array}{l}\text { The influences on and experiences of becoming nurse } \\
\text { entrepreneurs: a delphi study }{ }^{(31)}\end{array}$ & $\begin{array}{l}2003 \text { International Journal of } \\
\text { Nursing Practice }\end{array}$ & Australia & Misto & Management \\
\hline $\begin{array}{l}\text { The perceptions of KwaZulu-Natal nursing students about } \\
\text { the discipline }{ }^{(13)}\end{array}$ & 2000 Curationis & South Africa & Qualitative & Education \\
\hline $\begin{array}{l}\text { Entrepreneurship in Nursing: overview of companies in } \\
\text { the State of São Paulo } \\
\text { (35) }\end{array}$ & $\begin{array}{l}2015 \text { Revista Brasileira de } \\
\text { Enfermagem }\end{array}$ & Brazil & Quantitative & Business \\
\hline $\begin{array}{l}\text { Learning Incubator: an instrument to foster } \\
\text { entrepreneurship in Nursing } \\
\end{array}$ & $\begin{array}{l}2015 \text { Revista Brasileira de } \\
\text { Enfermagem }\end{array}$ & Brazil & Qualitative & Education \\
\hline $\begin{array}{l}\text { Entrepreneurial characteristics of nurses: a study in } \\
\text { southern Brazil(38) }\end{array}$ & 2016 Revista Baiana de Enfermagem & Brazil & Quantitative & Care \\
\hline $\begin{array}{l}\text { Entrepreneurship Psychological Characteristics of } \\
\text { Nurses }^{(15)}\end{array}$ & 2016 Acta Medica Iranica & Iran & Quantitative & Care \\
\hline $\begin{array}{l}\text { Iranian entrepreneur nurses' perceived barriers to } \\
\text { entrepreneurship: a qualitative study }{ }^{(32)}\end{array}$ & $\begin{array}{l}2016 \text { Iranian Journal of Nursing and } \\
\text { Midwifery Research }\end{array}$ & Iran & Qualitative & Business \\
\hline
\end{tabular}

\section{Studies Description}

The evolution of the studies analyzed improved from 1994 to 2016 , with a peak in 2009 , which concentrated five (16.1\%) articles. The 31 articles analyzed were published in 24 different journals. The journal with the highest number of articles selected was the Revista Brasileira de Enfermagem, with four (12.9\%) publications.

As to the country of publication, $12(38.7 \%)$ were made in Brazil, five (16.1\%) in the United States, four (12.9\%) in the United Kingdom, three (9.6\%) in Australia, two (6.4\%) in Canada, two in Iran (6.4\%), one (3.2\%) in Finland, one (3.2\%) in South Africa and one $(3.2 \%)$ in Sweden.

As far as the methodological approach was concerned, 21 (67.7\%) publications were qualitative studies, nine (29.1\%) quantitative studies and one (3.2\%) mixed research. In the tangent to the study design, 13 (42.1\%) were descriptive or exploratory-descriptive, four (12.9\%) were Grounded Theory, four (12.9\%) were ethnographic researches, three (9.6\%) were single or multiple case studies and seven (22.5\%) presented other methodological designs.

Regarding the context/setting in which the work was carried out, the classification was used: Care, Education, Management and
Business. The places classified as Care were hospitals, clinics and Basic Health Units. In the context of Education, included studies carried out in higher education institutions. The Management context included the same sites previously mentioned, but research was selected whose focus was specifically on the structures or administrative departments. In the context of Business, we considered the autonomous or private practice environments of nurses, such as companies and clinics.

Thus, the exclusive context of Nursing Care concentrated 11 articles (35.4\%), followed by the Education environment with eight (25\%), the Business environment with six (19.3\%) and the Management environment with two (6.4\%) studies. Four (12.9\%) studies were conducted in more than one context, such as the care, management and/or education environment.

\section{Concept of Entrepreneurship in Nursing}

The concept of entrepreneurship in Nursing is associated with a set of personal characteristics ${ }^{(9)}$. Nursing entrepreneurship is conceptualized as: having a sense of opportunity, being autonomous, independent, flexible, determined, innovative, 
proactive, self-confident, disciplined, communicative, responsible, taking calculated risks, acting in a holistic way, to conquer new care settings, to add value to the profession before society, to boost the country's economic growth, to carry out financial and conflict management, to have legislative awareness and to turn to the future $\mathrm{e}^{(10-13)}$.

In addition, one of the studies identified that entrepreneurial attitudes are associated mainly with young nurses with shorter work hours. Nurses over 43 years of age and with more than 17 years of graduation show less entrepreneurial tendency ${ }^{(14)}$.

The sense of opportunity also appears in the findings as the main characteristic of an entrepreneur in Nursing. The opportunity for Nursing is both the search for new fronts of professional activity, resulting in improvement for society, as well as the use of unusual situations in professional practice that will affect improvement in care, education, business or any other setting of the nurse's performance ${ }^{(10,15)}$.

\section{Typologies of Entrepreneurship in Nursing}

Three typologies of entrepreneurship in Nursing were identified: social entrepreneurship, entrepreneurship entrepreneurship and intrapreneurship, in this sequence of relevance.

Social entrepreneurship is a mechanism for mobilizing and transforming society. It is mediated by social intervention from the application of a systemic vision derived from the multiplicity of relationships, interactions and social associations. It is an alternative, dynamic and strategic process that enables innovative actions, products, services and organizations that are sustainable and engaged in social development ${ }^{(16-17)}$.

Social entrepreneurs identify what is not working and solve problems, alter the system, spread the solution and persuade individuals and collectives to seek new levels of development ${ }^{(18)}$. To be a social entrepreneur, the nurse must have technical, human and interactive competence, as well as identify and expand the opportunities that add social value. They must also be creative, innovative, capable of identifying opportunities and capturing resources within society ${ }^{(16-17,19)}$.

In order for nurses to become more and more social entrepreneurs, the investment of Nursing in proactive attitudes at both professional and social level is fundamental ${ }^{(17)}$. At the present time, it is necessary for nurses to develop an entrepreneurial culture, exploring new spaces that foster citizen participation through the development of proactive care methodologies focused on the individual as subject and actors of the story itself(20).

For this, investments from the professional point of view are required that cover the instances of management, teaching, research and Nursing care. With regard to teaching and management of education, it is necessary to adopt differentiated pedagogical strategies aimed at the training of social entrepreneur nurses ${ }^{(21-22)}$, as in the case of learning incubators ${ }^{(23)}$.

In the process of Nursing education, nurses are often trained to act as good employees and performers of orders. This is contrary to the social entrepreneurial logic, based on the creation or recreation of interactive and associative opportunities, as well as on the possibility of innovating and staging new spaces of professional action. Thus, it is necessary to awaken an entrepreneurial culture among university managers, professors and students of Nursing for universities to invest in the development of social inclusion technologies ${ }^{(16)}$.

With regard to care, social entrepreneur nurses can develop nursing activities such as appointments, visits and consultancies or activities such as gym classes, workshops and courses for people and/or communities in situations of vulnerability ${ }^{(24)}$. Thus, nurses can combine private and/or non-exclusive nursing activities focused on the health and needs of the community, with personal, economic and business interests that allow for growth, valorization and professional autonomy, after all, it is possible to create social nursing companies ${ }^{(18)}$.

To better explore social protagonism, social entrepreneur nurses should foster inclusive practices and develop political projects that express the social participation of nurses in the most different spaces of professional activity. They also need to be committed to the process of emancipation of the subject, protagonism and proactivity focused on education and health promotion $^{(20)}$.

In Brazil, the configuration of the Brazilian Unified Health System (SUS - Estratégia Saúde da Família) as a comprehensive universal public health system is an efficient way of approaching and diffusing social entrepreneurship among nurses. It was with the creation of SUS and later with the Family Health Strategy (FHS) that nurses expanded their performance and insertion in the community and social field, obtaining greater visibility from a setting with more professional opportunities. Therefore, SUS and FHS are strategies that drive and strengthen social entrepreneurship in Nursing in Brazil(25).

Entrepreneurship entrepreneurship is the type of business oriented entrepreneurship. Refers to the entrepreneurship of nurses entrepreneurs, who in their practice act autonomously ${ }^{(26-27)}$.

There are several fields of business nurses. There is business opportunities found in nursing activities, such as, for example, autonomic appointments with patients with wounds. In addition, there are also extremely innovative activities for the area, unrelated to the field of Nursing, as consultants in companies not associated with health ${ }^{(26)}$. In the United States, nursing appointment through advanced practice nurses is widespread, especially in rural areas. In this context, nurses perform a more autonomous work in comparison to other settings, since they identified an opportunity in the places where the doctors did not work ${ }^{(28)}$.

There are several motivating factors that have boosted the flow of care nurses to the business sector. Among them, the emergence of an opportunity in the health system stands out; interest in opening your own business; the search for professional satisfaction; the finding of a need in the market of the nursing activity that develops; financial independence; the emotional wear and tear of working long hours as an employee; and abusive and excessively demanding employment ${ }^{(11,26)}$.

However, there are also many difficulties for nurses who enter the business environment ${ }^{(29)}$. It is common, for example, that nurses start the activity they propose with their own financial investment, since there are few investments and incentives from the government and other health professionals. In addition, the beginning in the business field occurs without the total untying of formal employment, generating double or triple working hours ${ }^{(30-32)}$. 
Besides these difficulties, the articles selected also point to obstacles related to the history of the profession, which are related to knowledge barriers, personal barriers and ethical-legal barriers. Knowledge barriers are associated with little nursing training in subjects pertinent to the business sector, which has a characteristic and unique language that is unknown in the profession $^{(18,33-34)}$. Personal barriers vary from person to person but are usually linked to nurses' concern that starting a business may suggest disloyalty to current doctors and employers or to the fear that society will not be able to absorb the new health service performed by nurses, since the culture predominates that hospitals and doctors' offices are the only places that offer health services. The ethical-legal barriers, however, refer to the legislation of each state or country for the work of autonomous nurses ${ }^{(33)}$. Another barrier was the general perception of Nursing to work for love and not to earn money ${ }^{(28)}$.

In view of the above, business entrepreneurship in Nursing is based on the need to have responsibility, personal and professional commitment, good self-esteem, perseverance and determination to achieve the necessary success for the company ${ }^{(31)}$. In this sense, the entrepreneur nurse must have a holistic capacity, that is, have a vision of the whole, regardless of social, political or economic conditions ${ }^{(11)}$.

Therefore, to be a nurse entrepreneur is to work on his/her own, undertaking in a way that influences health, including himself/herself in the process and being autonomous enough to foster a reform of the health system ${ }^{(26)}$. Encouragement to the autonomous entrepreneurship of the nurse is fundamental for the profession, since it allows the conquest of new fields of action, social valorization of the profession and boosts the economic growth of the country, since the formed companies generate jobs to a portion of the population ${ }^{(11,35)}$.

Intrapreneurship or corporate entrepreneurship is related to entrepreneurs corporate employees, that is, entrepreneurs who do not own a business of their own, but who are entrepreneurs in existing public or private organizations ${ }^{(18,36)}$.

Intrapreneurship, despite having its own nomenclature, resembles the common entrepreneurship, since it has the purpose of situating the context of action of this entrepreneur. This, for example, does not prevent it from adding another purpose of enterprise, as is the case of the intrapreneur social, in which the workers of an organization themselves act as entrepreneurs in seeking transformation and social development ${ }^{(18)}$. However, intrapreneurs have to deal with the setting of action, obstacles related to institutional orthodoxy, it is up to these people to overcome them with creativity and determination ${ }^{(37)}$.

In public organizations, for example, intra-entrepreneurs must identify opportunities, problems and solutions, entering the team and dividing responsibilities. Public servants, in turn, for intrapreneurship, need to create legitimacy and freedom within the institution. This is not an easy task and may vary according to the position and the employment situation, which implies the use of social skills and alliances with persons in higher positions in the institution and/or external persons who provide economic resources or visibility for the institution. There are many criticisms in this medium of public organizations. In this way, intrapreneurs must be persistent, have good ideas and ability to create freedom of action ${ }^{(36,38)}$.
In the context of teaching, common to nursing practice, intrapreneurship skills of nurses were mentioned by one of the articles, which highlighted, from the point of view of educational management, the importance of innovation capacity, time management, communication and of negotiation ${ }^{(39)}$.

\section{DISCUSSION}

The scientific production about entrepreneurship in Nursing was increasing in the studied period, mainly in the Brazilian setting, although there is an international distribution of the publications. In addition, nurses were the most researched professionals in this subject. This can be explained by the increase in Nursing research in Brazil, impacted by the growth of Nursing graduate programs, as well as by the need to build visibility and consolidation of the profession as science, technology and innovation ${ }^{(5)}$.

Qualitative research was the methodological approach most used by the studies. This may be related to the considerable increase in the use of this approach in the field of Health in the last four decades, both nationally and internationally ${ }^{(40)}$. In addition, qualitative studies allow a better understanding of the meanings and perceptions that involve entrepreneurship in Nursing, considering their multiple dimensions and particularities.

Care settings were the most researched environments in the studies analyzed. A similar finding is found in a study that evidenced the emphasis of productions in the hospital context, which affects the centrality of this sector in health systems ${ }^{(41)}$ and also in scientific research. The concentration of research in this setting may also be related to the fact that most nurses work in hospitals, clinics and health centers.

The concept of entrepreneurship in Nursing meets the general concept of entrepreneurship. Although it presents itself in a polysemic way, the central aspect of the concept is related to the change, with the exploration of an opportunity, conversion or invention of some idea, as well as with the success achieved ${ }^{(2,42)}$.

Entrepreneurship in Nursing follows the perspective of creating, generating and developing an opportunity focused on nursing actions, be they in the scope of care, education or management. These findings corroborate with the results of another study that highlights opportunities and/or needs of the company/context/society as the initial motivations of the entrepreneurs. In this way, these entrepreneurs mobilize because they have skills and knowledge or visualize an opportunity through personal behavior intrinsic to the individual ${ }^{(43)}$.

Despite the convergence between the concept of entrepreneurship in Nursing found in the findings and the general concept of entrepreneurship in literature, it should be pointed out that few studies have been carried out with the purpose of tracing the profile, behavior and attitude of the entrepreneur nurse.

Regarding the types of entrepreneurship in Nursing, it is emphasized that they were defined with didactic purpose to express the activities coming from the entrepreneurial actions of the nurses. The social entrepreneurship was the typology with greater prominence in the scope of Nursing. This may be associated with the fact that nurses deal with social demands and provide nursing services geared to the most diverse social contexts.

The literature shows that social entrepreneurs differ from entrepreneurs themselves, because they do not sell or possess goods to 
sell, but they solve social problems, not being driven by markets, but driven by population segments in situations of social risk. Social entrepreneurs are individuals capable of creating innovative solutions to the most diverse problems of society. They have as characteristics the persistence, the ambition and the capacity of creation of new ideas that propitiate social change ${ }^{(44)}$. In this sense, we highlight the findings of one of the studies of this typology about the development of activities that are not specifically part of the nurses' scope of action, such as gymnastics classes.

In this context, SUS stands out as a social entrepreneurial environment, since it expands the performance of health professionals, especially nurses. Similar findings are described in a previous study that characterizes SUS health services as entrepreneurship-friendly environments. This characteristic assumes that the SUS promotes innovation within the health services, starting with the adoption of principles and guidelines that extend the entrepreneurial culture ${ }^{(45)}$.

The intrapreneurship in Nursing refers to the work of nurses who are entrepreneurs, that is, nurses who undertake in public and private organizations of third parties. Intrapreneurship is characterized as an agent of change and innovation in an organization whether public or private, whether or not for profit. However, in the context of public organizations, permeated by their own peculiar characteristics, this phenomenon becomes multifaceted and complex ${ }^{(46)}$.

Entrepreneurship business is related to nurses entrepreneurs who have developed their own business in their own way. Entrepreneurship, business or commercial entrepreneurship, as it is called in the literature, corresponds to the visualization of an opportunity by an individual with the possibility of being successful, resulting in profit for the entrepreneur ${ }^{(47)}$.

In view of the results of this review, the need for investments in the most different fields of Nursing is emphasized, such as teaching and management for the development of entrepreneurship and an entrepreneurial culture. The importance of entrepreneurial education in educational institutions is not only in terms of teaching to train future professionals for entrepreneurial activities, but also in the promotion of entrepreneurial educational management, since entrepreneurial educational management is a condition for entrepreneurial education ${ }^{(48)}$. In addition, the government's investment in entrepreneurial training is relevant, generating innovative business that modifies the national and international setting.

\section{Study limitations}

As a limitation of the study, the option to consult databases of the Health and Nursing area is highlighted. The inclusion of specific Administration databases in future studies could broaden the scope of entrepreneurship analysis in Nursing.

\section{Contributions to Nursing}

This study can contribute to the dissemination of the concept and the typologies of entrepreneurship in Nursing. Entrepreneurship can increase the visibility of the profession and foster the creation of new spaces for nurses. Thus, the need for new studies focusing on entrepreneurship in the context of university management is pointed out, since teaching has the potential to create and disseminate an entrepreneurial culture that can manifest itself in the multiple dimensions of nurses' professional practice.

\section{CONCLUSION}

The concept of entrepreneurship in Nursing is linked mainly to personal characteristics, which allows associating entrepreneurship with a behavior and/or profile and/or attitude of the nurse. Coupled with this behavior/profile/attitude, which some authors name spirit (entrepreneur), is the sense of opportunity. That is, besides the nurse having a different attitude, it is necessary to identify the opportunities in the settings of professional practice for the entrepreneurship to be revealed.

Regarding the types of entrepreneurship in Nursing, social entrepreneurship concentrated the largest number of selected publications. This may be related to the activity of the profession, whose main dimension is the care and well-being of the individual, family and society. In this typology, SUS appeared as an environment in which social entrepreneurship can be developed. It is important to pay attention to the fact that social entrepreneurship focuses on the mutual growth between society and entrepreneur, which may hinder the Nursing activity, which culturally dedicates itself to a know-how for love, to the detriment of its own valuation and economic gain.

Entrepreneurship encompasses the actuation of nurses who are autonomous professionally. This typology was the least present in the Brazilian setting. This raises the reflection on the strategies that can be developed by nurses for the development of the spirit of business and the search for good salaries and professional stability in addition to public tenders.

Intrapreneurship was the least frequent in the studies analyzed. However, it can be said that this typology best illustrates the entrepreneurial reality in Nursing, since most nurses work as employees in hospitals, health centers, clinics and other health services. Thus, it is pointed out the need to disseminate this type of entrepreneurship among nurses and students of Nursing.

\section{REFERENCES}

1. Slepcevic-Zach P, Stock M, Tafner G. Entrepreneurship Education at the University of Graz. In: Weber S, Oser FK, Achtenhagen F, Fretschner M, Trost S, editors. Becoming an entrepreneur [Internet] Rotterdam: SensePublishers; 2014 [cited 2017 Jun 27] p. 109-22. Available from: https://doi.org/10.1007/978-94-6209-596-0_7.

2. Almeida JG, Santos EJR, Ferreira JA, Albuquerque CP. Unemployment and entrepreneurship: from the ambiguity of the conceptual relationship to the efficacy of the social intervention practices. Plural [Internet]. 2013 [cited 2017 Jun 27];20(1):31-56. Available from: http:// www.revistas.usp.br/plural/article/view/69562/72134 Portuguese. 
3. Gomes AF, Lima JB, Cappelle MCA. From entrepreneurialism to the notion of entrepreneurial actions: theoretical reflections. Rev Alcance [Internet]. 2013 [cited 2017 Jun 27];20(2):203-20. Available from: http://siaiap32.univali.br/seer/index.php/ra/article/view/3796 doi http:// dx.doi.org/10.14210/alcance.v20n2.p203-220 Portuguese.

4. Backes DS. Vislumbrando o cuidado de enfermagem como prática social empreendedora [Thesis on the Internet]. Florianópolis (SC): Universidade Federal de Santa Catarina, Pós-Graduação em Enfermagem; 2008 [cited 2017 Jun 27]. Avaliable from: http://repositorio.ufsc. $\mathrm{br} / \mathrm{xmlui} /$ handle/123456789/91850

5. Erdmann AL, Andrade SR, Santos JLG, Oliveira RJT. The profile of nursing management graduates from the Nursing Programs in Southern Brazil. Rev Esc Enferm USP [Internet]. 2011 [cited 2017 Jun 27];45(Esp.):1551-7. Available from: http://www.scielo.br/pdf/reeusp/v45nspe/ en_v45nspea03.pdf doi: http://dx.doi.org/10.1590/0104-1169.3144.2394

6. Cardoso RJM, Graveto JMGN, Queiroz AMCA. The exposure of the nursing profession in online and print media. Rev. Lat Am Enfermagem [Internet]. 2014 [cited 2017 Jun 27]; 22(1):144-149. Available from: http://www.scielo.br/scielo.php?script=sci_arttext\&pid =S0104-11692014000100144 doi: 10.1590/0104-1169.3144.2394 English, Portuguese.

7. Polakiewicz RR, Daher DV, da Silva NF, Silva NF, Ferreira Júnior J, Ferreira ME. Potencialidades e vulnerabilidades do enfermeiro empreendedor: uma revisão integrativa. Persp Online Biol Saúde [Internet]. 2013 [cited 2017 Jun 27];11(3):53-79. Available from: http:// www.seer.perspectivasonline.com.br/index.php/biologicas_e_saude/article/view/14 doi: http://dx.doi.org/10.25242/8868311201314.

8. Whittemore R, Knafl K. The integrative review: updated methodology. J Adv Nurs [Internet] 2005; [cited 2017 Jun 27];52(5):546-53. Avaliable from: https://doi.org/10.1111/j.1365-2648.2005.03621.x.

9. Sales OP, Cruvinel DF, Silva DP, Santos LL. Enterprise teaching in Undergraduate Nursing Course at University Paulista (UNIP) Goiânia - Goiás. Rev Inst Ciênc Saúde [Internet]. 2008 [cited 2017 Jun 27];26(2):167-72. Available from: https://www.unip.br/comunicacao/publicacoes/ics/ edicoes/2008/02_abr_jun/V26_N2_2008_p167-172.pdf Portuguese.

10. Ferreira GE, Rozendo CA, Santos RM, Pinto EA, Costa ACS, Porto AR. Business characteristics of the future nurse. Cogitare Enferm [Internet]. 2013 [cited 2017 Jun 27];18(4):688-94. Available from: http://revistas.ufpr.br/cogitare/article/viewFile/34921/21675

11. Morais JA, Haddad MCL, Rossaneis MA, Silva LGC. Autonomous and business practices in nursing. Cogitare Enferm [Internet]. 2013 [cited 2017 Jun 27];18(4):695-701. Available from http://revistas.ufpr.br/cogitare/article/view/46422 doi: http://dx.doi.org/10.5380/ce.v18i4.46422

12. DeCarlo L. Advanced practice nurse entrepreneurs in multidisciplinary surgical-assisting partnership. AORN Journal [Internet]. 2005 [cited 2017 Jun 27];82(3):417-422,425-427. Available from: https://www.ncbi.nlm.nih.gov/pubmed/16309068

13. Uys LR. The perceptions of KwaZulu-Natal nursing students about the discipline. Curationis [Internet]. 2000 [cited 2017 Jun 27];23(1):79-86. Available from: https://www.ncbi.nlm.nih.gov/pubmed/11140034

14. Costa FG, Vaghetti HH, Martinello DFG, Mendes DP, Terra AC, Alvarez SQ et al. Enterprising tendencies of nurses in a university hospital. Rev Gaúcha Enferm [Internet]. 2013 [cited 2017 Jun 27];34(2):147-154. Available from: http://seer.ufrgs.br/RevistaGauchadeEnfermagem/article/ view/29112/27306

15. Dehghanzadeh MR, Kholasehzadeh G, Birjandi M, Antikchi E, Sobhan MR, Neamatzadeh H. Entrepreneurship psychological characteristics of nurses. Acta Med Iran [Internet]. 2016 [cited 2017 Jun 27];54(9):595-599. Available from: https://www.ncbi.nlm.nih.gov/pubmed/27832692

16. Backes DS, Erdmann AL. Education of nurses under the social enterprising view. Rev. Gaúcha Enferm [Internet]. 2009 [cited 2017 Jun 27];30(2):242-8. Available from: http://www.seer.ufrgs.br/RevistaGauchadeEnfermagem/article/view/7252 Portuguese.

17. Backes DS, Erdmann AL, Büscher A. Nursing care as an enterprising social practice: opportunities and possibilities. Acta Paul Enferm [Internet]. 2010 [cited 2017 Jun 27];23(3):341-7. Available from: http://www.scielo.br/scielo.php?script=sci_arttext\&pid =S0103-21002010000300005 doi: http://dx.doi.org/10.1590/S0103-21002010000300005

18. Dawes D. How nurses can use social enterprise to improve services in health care. Nurs Times [Internet]. 2009 [cited 2017 Jun 27];105(1):225. Available from: https://www.ncbi.nlm.nih.gov/pubmed/19330985

19. Boore J, Porter S. Education for entrepreneurship in nursing. Nurse Educ Today [Internet]. 2011[cited 2017 Jun 27];31(2):184-91. Available from: https://www.ncbi.nlm.nih.gov/pubmed/20594624

20. Backes DS, Backes MS, Erdmann AL. Promoting citizenship through nursing care. Rev Bras Enferm [Internet]. 2009 [cited 2017 Jun 27];62(3):430-4. Available from: http://www.scielo.br/pdf/reben/v62n3/15.pdf doi: http://dx.doi.org/10.1590/S0034-71672009000300015 Portuguese

21. Wilson $\mathrm{A}$, Whitaker $\mathrm{N}$, Whitford D. Rising to the challenge of health care reform with entrepreneurial and intrapreneurial nursing initiatives. Online J Issues Nurs. 2012;17(2):5. doi: 10.3912/OJIN

22. Roncon PF, Munhoz S. Do nursing students have entrepreuner profile? Rev Bras Enferm [Internet]. 2009 [cited 2017 Jun 27];62(5):695-700 Available from: http://www.scielo.br/scielo.php?script=sci_arttext\&pid=S0034-71672009000500007 doi: http://dx.doi.org/10.1590/S003471672009000500007 Portuguese.

23. Backes DS, Obem MK, Pereira SB, Gomes CA, Backes MTS, Erdmann AL. Learning Incubator: an instrument to foster entrepreneurship in Nursing. Rev Bras Enferm [Internet]. 2015 [cited 2017 Jun 27];68(6):1 103-08. Available from: Available from: http://www.scielo.br/scielo. php?pid=S0034-71672015000601103\&script=sci_arttext doi: http://dx.doi.org/10.1590/0034-7167.2015680615i Portuguese.

24. Farmer J, Kilpatrick S. Are rural health professionals also social entrepreneurs? Soc Sci Med [Internet]. 2009 [cited 2017 Jun 27];69(11):16518. Available from: https://www.ncbi.nlm.nih.gov/pubmed/19783086 doi:10.1016/j.socscimed.2009.09.003. 
25. Backes DS, Backes MS, Erdmann AL, Büscher A. The role of the nurse in the Brazilian Unified Heath System: from community health to the family health strategy. Ciênc Saúde Coletiva [Internet]. 2012 [cited 2017 Jun 27];17(1):223-30. Available from: http://www.scielo.br/scielo. php?script=sci_arttext\&pid=S1413-81232012000100024 doi: http://dx.doi.org/10.1590/S1413-81232012000100024 Portuguese.

26. Wall S. Self-employed nurses as change agents in healthcare: strategies, consequences, and possibilities. J Health Organ Manag [Internet]. 2014 [cited 2017 Jun 27];28(4):511-31. Available from: https://www.ncbi.nlm.nih.gov/pubmed/25241597

27. Wall S. Nursing entrepreneurship: motivators, strategies and possibilities for professional advancement and health system change. Nurs Leadersh (Tor Ont) [Internet]. 2013 [cited 2017 Jun 27];26(2):29-40. Available from: https://www.ncbi.nlm.nih.gov/pubmed/23809640

28. Sharp DB, Monsivais D. Decreasing barriers for nurse practitioner social entrepreneurship. J Am Assoc Nurse Pract [Internet]. 2014 [cited 2017 Jun 27];26(10):562-6. Available from: https://www.ncbi.nlm.nih.gov/pubmed/24824857 doi:10.1002/2327-6924.12126

29. Austin L, Luker K, Ronald M. Clinical nurse specialists as entrepreneurs: constrained or liberated. J Clin Nurs [Internet]. 2006 [cited 2017 Jun 27];15(12): 1540-9. Available from: https://www.ncbi.nlm.nih.gov/pubmed/17118076 doi: 10.1111/j.1365-2702.2006.01576.x

30. Crofts AJ. Entrepreneurship the realities of today. J Nurs. Midwifery[Internet]. 1994[cited 2017 Jun 27];39(1):39-42. Available from: https:// www.ncbi.nlm.nih.gov/pubmed/8195892

31. Wilson A, Averis A, Walsh K. The influences on and experiences of becoming nurse entrepreneurs: a Delphi study. Int J Nurs Pract [Internet]. 2003 [cited 2017 Jun 27];9(4):236-45. Available from: https://www.ncbi.nlm.nih.gov/pubmed/12887375

32. Jahani S, Abedi H, Elahi N, Fallahi-Khoshknab M. Iranian entrepreneur nurses' perceived barriers to entrepreneurship: a qualitative study. Iran J Nurs Midwifery Res [Internet]. 2016 [cited 2017 Jun 27];21(1):45-53. Available from: https://www.ncbi.nlm.nih.gov/pubmed/26985222 doi: 10.4103/1735-9066.174749.

33. Elango B, Hunter GL, Winchell M. Barriers to nurse entrepreneurship: a study of the process model of entrepreneurship. J Am Acad Nurse Pract [Internet]. 2007 [cited 2017 Jun 27];19(4):198-204. Available from: https://www.ncbi.nlm.nih.gov/pubmed/17430540 doi: 10.1111/j.1745-7599.2007.00215.x.

34. Sankelo M, Akerblad L. Nurse entrepreneurs' attitudes to management, their adoption of the manager's role and managerial assertiveness. J Nurs Manag [Internet]. 2008 [cited 2017 Jun 27];16(7):829-36.. Available from: https://www.ncbi.nlm.nih.gov/pubmed/19017245 doi: 10.1111/j.1365-2834.2008.00917.x

35. Andrade AC, Dal Bem LW, Sanna MC. Entrepreneurship in Nursing: overview of companies in the State of São Paulo. Rev Bras Enferm [Internet]. 2015[cited 2017 Jun 27];68(1):40-4. Available from: http://www.scielo.br/pdf/reben/v68n1/0034-7167-reben-68-01-0040.pdf doi: http://dx.doi.org/10.1590/0034-7167.2015680106p.

36. Sundin E, Tillmar M. A nurse and a civil cervant changing institutions: entrepreneurial processes in different public sector organizations. Scand J Manag [Internet]. 2008 [cited 2017 Jun 27];24(2):113-24. Available from: http://www.sciencedirect.com/science/article/pii/ S0956522108000298 doi: https://doi.org/10.1016/j.scaman.2008.03.006

37. Darbyshire $\mathrm{P}$, Downes $\mathrm{M}$, Collins C, Dyer S. Moving from institutional dependence to entrepreneurialism. Creating and funding a collaborative research and practice development position. J Clin Nurs [Internet]. 2005 [cited 2017 Jun 27];14(8):926-34. Available from: http://onlinelibrary.wiley.com/doi/10.1111/j.1365-2702.2005.01132.x/full doi: https://doi.org/10.1111/j.1365-2702.2005.01132.x

38. Carvalho DP, Vaghetti HH, Dias JS, Rocha LP. Entrepreneurial characteristics of nurses: a study in southern Brazil. Rev Baiana Enferm [Internet]. 2016 [cited 2017 Jun 27];30(4):1-11. DOI 10.18471/rbe.v30i4.16803. Available from: https://portalseer.ufba.br/index.php/ enfermagem/article/view/16803/pdf Portuguese.

39. Camiah S. New skills required of nurse tutors in the UK: a study within two Project 2000 pilot schemes for pre-registration nursing courses. Nurs Educ Today [Internet]. 1998 [cited 2017 Jun 27];18(2):93-100. Available from: https://www.ncbi.nlm.nih.gov/pubmed/9592507

40. Medeiros M. Thinking about qualitative research. Rev Eletr Enferm [Internet]. 2012 [cited 2017 Jun 27];14(2):226-7. Available from: https:// www.revistas.ufg.br/fen/article/view/13628/11616

41. Santos JLG, Erdmann AL, Andrade SR, Mello ALSF, Lima SBS, Pestana AL. Nursing governance: an integrative review of the literature. Rev Esc Enferm USP [Internet]. 2013 [cited 2017 Jun 27];47(6):1417-25. Available from: http://www.scielo.br/scielo.php?script=sci_arttext\&pid $=$ S0080-62342013000601417 Portuguese.

42. Drucker PF. Inovação e espírito empreendedor: prática e princípios. São Paulo: Cengage Learning; 2012. 960 p.

43. Meza MLFG, Rissete CR, Cunha SK, Machado JP, Bastos Júnior PA, Greco SMSS. O perfil do empreendedorismo nos países latino-americanos na perspectiva da capacidade de inovação. Rev Micro Pequena Empres [Internet]. 2008 [cited 2017 Jun 27];2(2):58-75. Available from: http://ibqp.org.br/wp-content/uploads/2016/09/O-Perfil-do-Empreendedorismo-nos-Pa\%C3\%ADses-Latino-Americanos-na-Perspectivada-Capacidade-de-Inova\%C3\%A7\%C3\%A3o.pdf

44. Duarte TL, Madruga LRRG, Becker DV, Ávila LV. Desenvolvimento sustentável e empreendedorismo social: um estudo multicaso sobre o impacto de um programa social em organizações não governamentais. Rev UNIABEU [Internet]. 2013 [cited 2017 Jun 27];6(14):251-74. Available from: http://revista.uniabeu.edu.br/index.php/RU/article/view/1003

45. Souza Neto B, Oliveira MM. Entrepreneurial business analysis: the study multi-case of public institutions of Minas Gerais belonging to SUS. Biochem Biotechnol Rep [Internet]. 2013 [cited 2017 Jun 27];2(2):146-9. Available from: http://www.uel.br/revistas/uel/index.php/bbr/ article/viewFile/15598/12868

46. Coelho MLGMM. Intraempreendedorismo e a inovação na gestão pública federal. Rev Serv Público [Internet]. 2010 [cited 2017 Jun 
27];61(3):233-47. Available from: https://revista.enap.gov.br/index.php/RSP/article/viewFile/48/44

47. Leal AL, de Freitas AAF, Coelho S. A percepção de oportunidades no contexto do empreendedorismo social. Rev Bras Admin Cient [Internet]. 2014 [cited 2017 Jun 27];5(3): 236-51. Available from: http://www.anpad.org.br/admin/pdf/2013_EnANPAD_ESO2061.pdf

48. Santos ZMML, Silva LF. Gestores empreendedores e seus papéis na performance das escolas de referência do Estado de Pernambuco. Rev Int Investig Ciênc Soc [Internet]. 2012 [cited 2017 Jun 27]; 8(1):81-100. Available from: http://scielo.iics.una.py/scielo. php?pid=S2226-0002012000100006\&script=sci_abstract 